\title{
Characterization of extracellular amylase from Bacillus sp. strain RU1
}

\author{
Aleem Basha Pinjari*, Vijayalakshmi Kotari \\ Department of Biotechnology, Rayalaseema University, Kurnool - 518 007, Andhra Pradesh, India
}

\section{ARTICLE INFO}

Article history:

Received on: November 28, 2017

Accepted on: January 16, 2018

Available online: April 05, 2018

Key words: Bacillus sp.,

Extracellular amylase,

Characterization,

Carbon sources,

Temperature, $\mathrm{pH}$

\section{ABSTRACT}

The present study reveals the isolation of amylolytic bacteria from the industrially contaminated soils collected around Kurnool district, Andhra Pradesh, India. A bacterium belonging to genus Bacillus was isolated by serial dilution method. The bacterium was designated as Bacillus sp. strain RU1. Compared to others, strain RU1 has shown maximum amylase activity with starch as substrate. Various parameters have been optimized for enhancing the production of amylase which includes carbon sources, nitrogen sources, substrate concentration, and inoculum size. The results have shown fructose and ammonium carbonate are the best carbon and nitrogen sources for amylase production. Crude amylase enzyme studies revealed the optimum temperature and $\mathrm{pH}$ as $45^{\circ} \mathrm{C}$ and 10.0 . Therefore, the amylase enzyme isolated in the present study will find applications in the industry as the enzyme is active at moderately thermophilic and at alkaline $\mathrm{pH}$.

\section{INTRODUCTION}

Microorganisms play an important role in producing several industrially important enzymes which play a key role in hydrolyzing the complex molecules [1,2]. Although microbes produce several enzymes, amylase is the first enzyme that was produced industrially [1]. Among the extracellular hydrolytic enzymes, amylases occupy a special status because of their high industrial value, and they cover approximately $30 \%$ of the enzyme market $[3,4]$. Amylases which function as glycosidic hydrolases hydrolyze starch into respective mono, di, tri, and oligomers. Hence, they are also referred as digestive enzymes and are the first enzyme produced on the industrial scale from a fungal source which has application in the treatment of digestive disorders [1]. Amylases also possess numerous applications especially in biotechnological industries such as pharmaceutical's, textiles, detergents, paper, and food [1,5-7]. Amylases could be isolated from different sources such as from animals, plants, and microbes. Microbial amylases derived from bacteria, fungi, yeasts, and actinomycetes have replaced the other sources because of its availability and ease of isolation. Amylases from microbial origin have some specific properties which ensemble them for various industrial applications. These properties include differences in thermotolerance, $\mathrm{pH}$ maxima, and optimum temperature [8,9]. $\alpha$-amylases produced from

*Corresponding Author

Aleem Basha Pinjari, Department of Biotechnology, Rayalaseema University, Pasupala Road,

Kurnool-518007,

Andhra Pradesh, India.

Email: aleemunn@gmail.com the Bacillus genus have a special status in terms of industrial applications, and much importance has been given to the optimization parameters for production processes $[9,10]$. In the past, amylases have been isolated from bacteria screened from natural locations such as kitchen waste, domestic waste, and soil samples which were not that much stable in industrial applications. At present, researchers are concentrating on isolating unusual microbial amylases found in alkalophilic and acidophilic bacteria which can withstand the harsh conditions during the industrial bioprocesses. In the present study, the amylase producing bacterium was isolated from industrially contaminated soils, optimized for production and characterized the crude amylase.

\section{MATERIALS AND METHODS}

\subsection{Media and Growth Conditions}

The following media were used to propagate the bacteria. All media were sterilized by autoclaving for $15 \mathrm{~min}$ at $15 \mathrm{lb} / \mathrm{Sq}$.

\subsubsection{Luria bertani (lb) medium}

The LB broth was prepared by dissolving peptone $(10 \mathrm{~g})$, yeast extract $(5 \mathrm{~g})$, and sodium chloride $(10 \mathrm{~g})$ in an appropriate volume $(500 \mathrm{ml})$ of distilled water. The contents were stirred, and finally, the volume was brought to $1 \mathrm{~L}$ with distilled water. The $\mathrm{LB}$ broth $\mathrm{pH}$ was brought to $\mathrm{pH} 7.0$ with $1 \mathrm{~N} \mathrm{NaOH}$ and then sterilized it by autoclaving. The LB agar plates were prepared by adding $2 \%$ agar to LB broth.

\subsubsection{Preparation of starch agar plates}

The starch agar plates were prepared in LB agar medium supplemented with $1 \mathrm{~g}$ starch for $100 \mathrm{ml} \mathrm{LB}$ agar medium. Initially, the LB agar was 
Pinjari and Kotari: Extracellular amylase from Bacillus sp. strain RU1 2018;6(3):29-34

prepared by dissolving peptone $(1 \mathrm{~g})$, yeast extract $(0.5 \mathrm{~g})$ and sodium chloride $(1 \mathrm{~g})$ in $90 \mathrm{ml}$ distilled water, $\mathrm{pH}$ was adjusted to $\mathrm{pH} 7.0$ with $1 \mathrm{~N} \mathrm{NaOH}$, agar was added at $2 \%$ concentration. Then, this solution was sterilized by autoclaving for $15 \mathrm{~min}$ at $15 \mathrm{lb} / \mathrm{Sq}$ pressure. Starch was prepared separately at $10 \mathrm{~g} / 100 \mathrm{ml}$ and sterilized by autoclaving as described above. After cooling to $45^{\circ} \mathrm{C}, 10 \mathrm{ml}$ of starch solution was added to the sterile LB agar medium under aseptic conditions. The contents were mixed properly. These plates after solidification were stored at $4^{\circ} \mathrm{C}$ by keeping them in a special container. The starch agar plates were used as and when required.

\subsection{Isolation of Amylase Producing Bacteria from Industrial Contaminated Soil Samples}

The soil sample $(10 \mathrm{~g})$ collected was diluted in $100 \mathrm{ml}$ of normal saline $(0.85 \%$ of sodium chloride). The conical flask containing the soil sample was kept aside for a couple of hours. After the settling of the soil particles, the clear supernatant was collected separately and serially diluted. The dilution was done up to $10^{-8}$ to reduce the number of colonies on the plate. The serially diluted sample specifically $10^{-8}$ sample was spread on to LB agar plates supplemented with starch. Then, the plates were incubated at $37^{\circ} \mathrm{C}$ for 2 days. The strains growing on starch agar plate were collected separately, and each colony was cultured separately and tested for their amylolytic activity. Each isolated single colonies were streaked onto starch agar plates and incubated for 2 days at $37^{\circ} \mathrm{C}$ for measuring their amylolytic activity. The positive colonies showing clear zone on starch agar plate after flooding with iodine solution were selected for further studies. These colonies were preserved in glycerol cultures at $-20^{\circ} \mathrm{C}$ [11]

\subsection{Morphological and Biochemical Characterization of Strain RU1}

The morphology of strain RU1 cultured on a LB agar plate at $37^{\circ} \mathrm{C}$ was observed under a microscope. Gram staining was done to differentiate between Gram-positive and Gram-negative. Physiological and biochemical analyses were performed by referring to Bergey's manual [12].

\subsection{Amylase Enzyme Assay}

The amylase enzyme assay was performed by estimating the reducing sugars released by the action of $\alpha$-amylase enzyme on starch. The reducing sugars were estimated by dinitrosalicylic acid (DNS) method. The method involves incubation of substrate solution with enzyme, followed by incubation at $37^{\circ} \mathrm{C}$ for $10 \mathrm{~min}$ and then DNS reagent was added before incubating in boiling water bath for $5 \mathrm{~min}$. The supernatant was collected after cooling and then the absorbance was measured at $540 \mathrm{~nm}$. The absorbance values of both enzyme blank and substrate blank were subtracted from the absorbance of test sample to calculate the activity [13]. Under standard conditions, the enzyme activity was calculated as the amount of the enzyme responsible for liberating $1 \mu \mathrm{g}$ of maltose per minute per milliliter as one unit. From the results of enzyme assay, the highest amylase yielding isolate was selected for further studies.

\subsection{Influence of Carbon Sources on Amylase Enzyme Production}

The influence of carbon sources on the amylase enzyme production was studied by incorporating simple and complex sugars (sucrose, maltose, lactose, glucose, and fructose) as carbon sources. Each source was used at a concentration of $1 \%(w / v)$ to replace carbon. Amylase
Table 1: Morphological characteristics of strain RU1

\begin{tabular}{ll}
\hline Form & Irregular \\
Size & Large \\
Color & Milky white \\
Surface & Moist \\
Gram staining & Gram-positive
\end{tabular}

Table 2: Biochemical characteristics of strain RU1

\begin{tabular}{ll}
\hline Starch hydrolysis & Positive \\
Oxidase test & Positive \\
Catalase test & Positive \\
Urease test & Positive \\
Nitrate reduction & Positive \\
Voges-Proskauer test & Positive \\
Methyl red test & Positive \\
$\mathrm{H}_{2} \mathrm{~S}$ production & Positive \\
Indole test & Positive
\end{tabular}

yield was determined after $24 \mathrm{~h}$ of incubation at $37^{\circ} \mathrm{C}$ with shaking at 150-200 rpm. After production, the yield was estimated quantitatively.

\subsection{Influence of Nitrogen Sources on Amylase Enzyme Production}

The influence of nitrogen sources for amylase production was determined with simple nitrogen sources such as sodium nitrate, potassium nitrate, ammonium carbonate, urea, and ammonium chloride as the nitrogen source instead of yeast extract. Each source was used at a concentration of $1 \%(\mathrm{w} / \mathrm{v})$ to replace nitrogen sources. Amylase yield was determined after $24 \mathrm{~h}$ of incubation at $37^{\circ} \mathrm{C}$ with shaking at 150-200 rpm. After production, the yield was estimated quantitatively.

\subsection{Influence of Substrate Concentration on Amylase Enzyme Production}

The influence of substrate concentration on amylase enzyme production was studied with different concentrations $(1 \%, 3 \%, 5 \%$, and $10 \%$ ) of starch solution. The media components are kept constant except starch solution concentration. The cultures were grown up to $24 \mathrm{~h}$ at $37^{\circ} \mathrm{C}$ with shaking at $150-200 \mathrm{rpm}$. After production, the yield was estimated quantitatively.

\subsection{Influence of Inoculum on Amylase Enzyme Production}

The influence of inoculum size on amylase enzyme production was studied with different percentages of $1 \%, 3 \%$, and $5 \%$ of inoculum. The media components and starch solution concentrations were kept constant except inoculum percentage. The cultures were grown up to $24 \mathrm{~h}$ at $37^{\circ} \mathrm{C}$ with shaking at $150-200 \mathrm{rpm}$. After production, the yield was estimated quantitatively.

\subsection{Role of pH on Crude Amylase Enzyme Activity}

To study the $\mathrm{pH}$ effect on crude amylase enzyme activity, different buffers were selected in the $\mathrm{pH}$ range of $\mathrm{pH} 5.0-\mathrm{pH} 10.0$ at $37^{\circ} \mathrm{C}$. The casein $1 \%(\mathrm{w} / \mathrm{v})$ was used as a substrate. The buffers selected for $\mathrm{pH} 5.0$ are the acetic acid buffer, the phosphate buffer for $\mathrm{pH} 8.0$, and the glycine- $\mathrm{NaOH}$ buffer for $\mathrm{pH} 10.0$. 


\subsection{Role of Temperature on Crude Amylase Enzyme Activity}

To study the role of temperature on crude amylase enzyme activity, different temperatures were selected starting from $25^{\circ} \mathrm{C}$ to $70^{\circ} \mathrm{C}$. The amylase enzyme activity was studied at these selected temperatures using starch as substrate. In four different tubes, the crude amylase along with substrate was incubated at different temperatures $\left(25^{\circ} \mathrm{C}, 37^{\circ} \mathrm{C}\right.$, $45^{\circ} \mathrm{C}$, and $70^{\circ} \mathrm{C}$ ). The amylase activities were measured after incubation.

\subsection{Comparison of Amylase Activity of Bacillus sp. Strain RU1 with Bacillus subtilis}

To compare the amylase activity of both strains they were grown under same environmental conditions. Both strains were inoculated in LB broth supplemented with starch $(1 \%)$. They were grown at $37^{\circ} \mathrm{C}$ with shaking at 150-200 rpm. After incubation, the supernatant was collected from both strains. The amylase enzyme assay was performed using the supernatant as a source of enzyme.

\section{RESULTS AND DISCUSSION}

Amylases which hydrolyze complex carbohydrate substrate such as starch to simple sugars have a remarkable value in many industries. This application excited many researchers to isolate novel amylases with special characteristics which outfit them to industrial applications. Microorganisms which prevail in almost all environments have been selected over plant and animal sources for isolating novel amylases. Studies on amylase enzymes from different geographical regions revealed important properties with respect to substrate specificity and optimal activity pertaining to temperature and $\mathrm{pH}[8,9]$. The selection of an enzyme such as $\alpha$-amylase for an industry majorly requires remarkable properties which can be applied for industrial processes [14]. Most of the amylases used in industrial applications are majorly from Bacillus genus $[9,10]$.

\subsection{Isolation of the Bacterium from Soil and Maintenance}

A total of 10 bacteria have been isolated from soil samples during the screening of amylase enzyme. Out of 10 bacteria, three bacteria have shown a positive reaction for amylase enzyme by the formation of a zone of starch hydrolysis around the colonies on starch agar plates. In the amylase enzyme assay, strain RU1 showed the maximum activity when compared with other two strains, and hence, strain RU1 was selected for further optimization studies [Figure 1]. To preserve strain

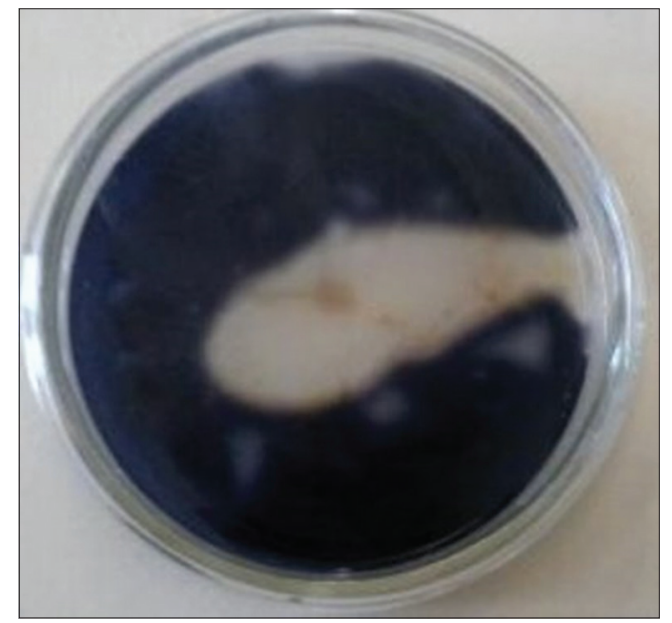

Figure 1: Amylase activity (zone of clearance) of strain RU1.
RU1, it was grown to log phase, harvested and preserved at $-20^{\circ} \mathrm{C}$ in glycerol broth media.

\subsection{Morphological and Biochemical Characterization of Strain RU1}

The colonies of strain RU1 grown on nutrient agar plates at $37^{\circ} \mathrm{C}$ for 24 $\mathrm{h}$ appeared as large milky white Table 1 . Biochemical characteristics of strain RU1 showed that it is aerobic and Gram-positive. The strain RU1 exhibited positive reactions for oxidase test, catalase test, urease test, nitrate reduction, and Voges-Proskauer test. The strain RU1 showed a negative reaction with methyl red, $\mathrm{H}_{2} \mathrm{~S}$ production, and indole tests Table 2 . These characteristics correspond to the phenotypic characteristics of a Bacillus sp. Hence, the strain isolated in the present study designated as Bacillus sp. strain RU1.

\subsection{Influence of Carbon Sources on Amylase Enzyme Production}

In general, the growth of bacterium and the enzyme production were influenced by different carbon sources [15]. In the current study also the amylase enzyme production was influenced by the carbon sources. The carbon sources (monosaccharides or polysaccharides) are replaced with starch in the medium. The highest $\alpha$-amylase production was observed in the medium supplemented with fructose $(1680 \mathrm{U} / \mathrm{mg})$ and maltose $(1680 \mathrm{U} / \mathrm{mg})$ [Figure 2]. Other carbon sources also produced the enzyme but the when compared with the above carbon sources, the production is low. Even though starch is the preferred substrate for producing amylase in most of the Bacillus sp. simple sugars such as glucose [16], fructose [17], maltose [5], and lactose [18] have been reported to produce more enzyme production compared to starch. Recent reports have shown the involvement of catabolite repression with easily metabolizable substrates such as glucose and fructose in amylase enzyme production [19]. The current study results also show the same effect with respect to glucose $(840 \mathrm{U} / \mathrm{mg})$ but not with fructose which has shown highest production, in fact, more than starch [Figure 2].

\subsection{Influence of Nitrogen Sources on Amylase Enzyme Production}

In many microorganisms, the influence of nitrogen sources on amylase enzyme production was studied [20]. Earlier reports have shown the organic nitrogen sources for instance yeast extract [21],

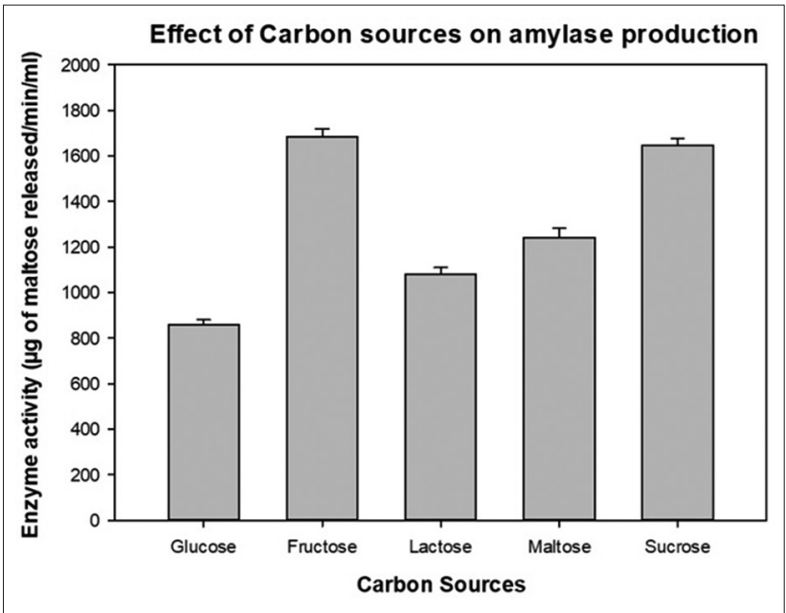

Figure 2: Influence of carbon sources on amylase enzyme production in strain RU1. Bars signify standard deviations for three replicates. 
tryptone and peptone influenced the amylase enzyme production [22]. Inorganic nitrogen sources such as ammonium ions and nitrate ions also influence the production of the $\alpha$-amylase [17]. In our study, high amount of amylase was produced in the media supplemented with inorganic nitrogen sources such as ammonium carbonate $(1680 \mathrm{U} /$ $\mathrm{mg}$ ) and sodium nitrate $(1560 \mathrm{U} / \mathrm{mg})$ followed by ammonium chloride (1440 U/mg) [Figure 3]. Comparatively amylase production was less in the media supplemented with potassium nitrate $(960 \mathrm{U} / \mathrm{mg})$ [Figure 3]. Although it showed differences in the production of the enzyme it utilized most of the inorganic nitrogen sources without any inhibition which is observed in some microorganisms [18,22].

\subsection{Influence of Substrate Concentration on Amylase Enzyme Production}

A set of different substrate concentrations of starch starting from $1 \%$ to $10 \%$ were selected to study their influence on amylase enzyme production. High yield of amylase was observed [Figure 4] in 10\% substrate concentration $(960 \mathrm{U} / \mathrm{mg})$. As the substrate concentration increased the amylase production was increased. The graph clearly showed the increments in amylase production with the increase of substrate concentration.

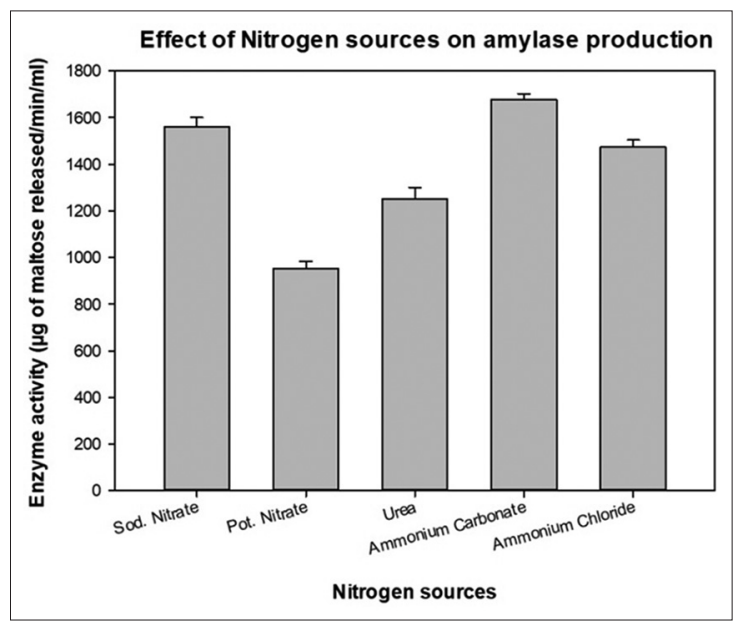

Figure 3: Influence of nitrogen sources on amylase enzyme production in strain RU1. Bars signify standard deviations for three replicates.

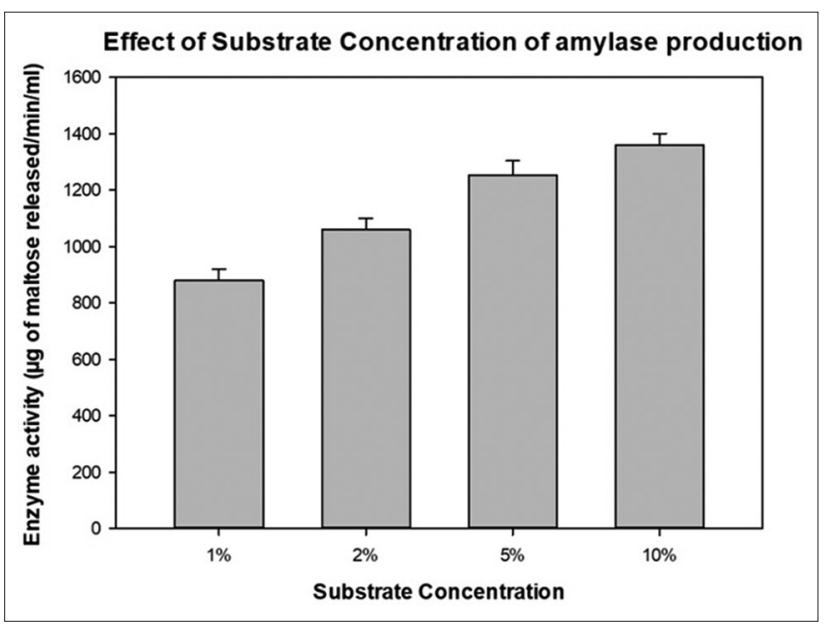

Figure 4: Influence of substrate concentration on amylase enzyme production in strain RU1. Bars signify standard deviations for three replicates.

\subsection{Influence of Inoculum Size on Amylase Enzyme Production}

The size of the inoculum also influenced the amylase enzyme production. Previous reports have shown that the optimal inoculum size as $2 \%$ to produce maximum $\alpha$-amylase production [23]. Increase in the inoculum size reduced the growth of the bacterium and enhanced the accumulation of bye products thereby reducing the enzyme production [24]. Therefore, the knowledge about the inoculum size is prerequisite to employ the enzyme in fermentation studies [19]. In contrast to above studies, our strain showed results where it has shown a linear relationship with respect to inoculum size. Different percentages of inoculums were investigated for amylase production. High yield of amylase production was observed [Figure 5] in $10 \%$ inoculum. Amylase production has shown a gradual increase with an increase in the inoculation from $1 \%$ to $10 \%$ inoculums.

\subsection{Role of pH on Crude Amylase Enzyme Activity}

In general, any changes in $\mathrm{pH}$ will affect the enzyme activity. Enzymes which are sensitive to $\mathrm{pH}$ may undergo drastic changes in terms of function by the modification of charges in active site leading to disruption of the enzyme-substrate complex. Changes in $\mathrm{pH}$ can also lead to disruption of bonds which are essential for

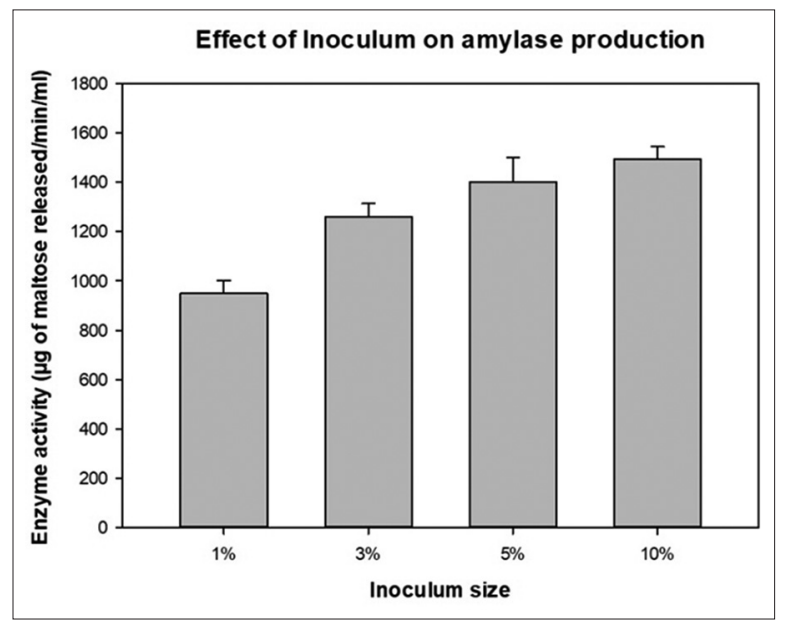

Figure 5: Influence of inoculum sizes on amylase enzyme production in strain RU1. Bars signify standard deviations for three replicates.

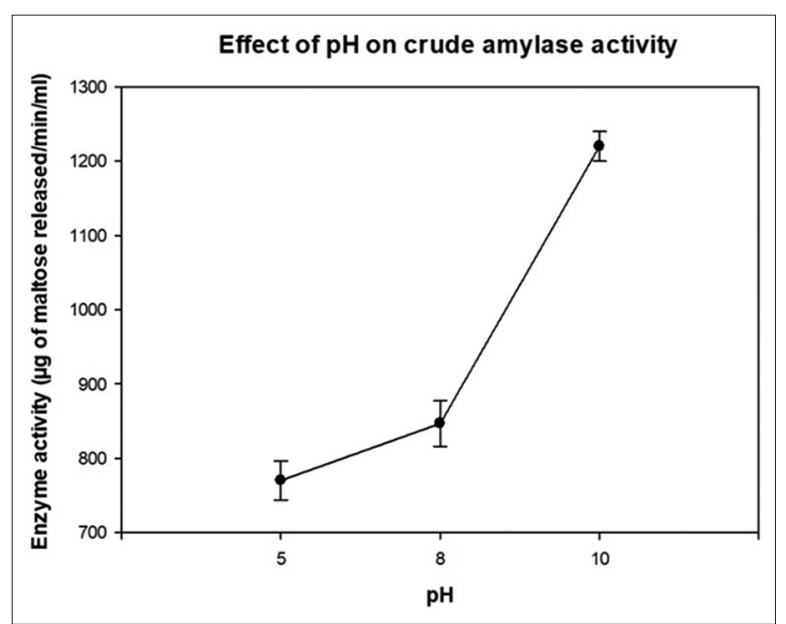

Figure 6: Role of $\mathrm{pH}$ on crude amylase enzyme activity in strain RU1. Bars signify standard deviations for three replicates. 
maintaining the tertiary structure of enzymes [25]. Even changes in $\mathrm{pH}$ affect morphological characteristics such as cell shape, size, and the water content in the cell and also cell complexity leading to changes in secretion of enzymes. In this study, the amylase enzyme activity of strain RU1 was measured in different buffers exhibiting different $\mathrm{pHs}$ in the range of $\mathrm{pH}$ 5-10. The strain RU1 optimal $\mathrm{pH}$ for amylase enzyme activity was determined as $\mathrm{pH} 10$ [Figure 6]. Most of the amylase producing Bacillus strains exhibits optimum $\mathrm{pH}$ for their amylase enzyme activity in the range of pH 6-9 [26-28].

\subsection{Role of Temperature on Crude Amylase Enzyme Activity}

Several strains in Bacillus genus have shown that the temperature for $\alpha$-amylase activity ranges from $37^{\circ} \mathrm{C}$ to $80^{\circ} \mathrm{C}$ [29]. Although they exhibit activity at a wide range of temperature, many Bacillus sp. have shown their optimal temperature for amylase activity as $40^{\circ} \mathrm{C}[5,30]$. In this study, the $\alpha$-amylase enzyme activity was studied by incubating the reaction mixtures at varied temperatures in the range of $37^{\circ} \mathrm{C}-70^{\circ} \mathrm{C}$. Our strain RU1 has shown activity at all temperatures but the maximal activity was observed at $45^{\circ} \mathrm{C}$ [Figure 7]. Above this optimal temperature, the activity was decreased.

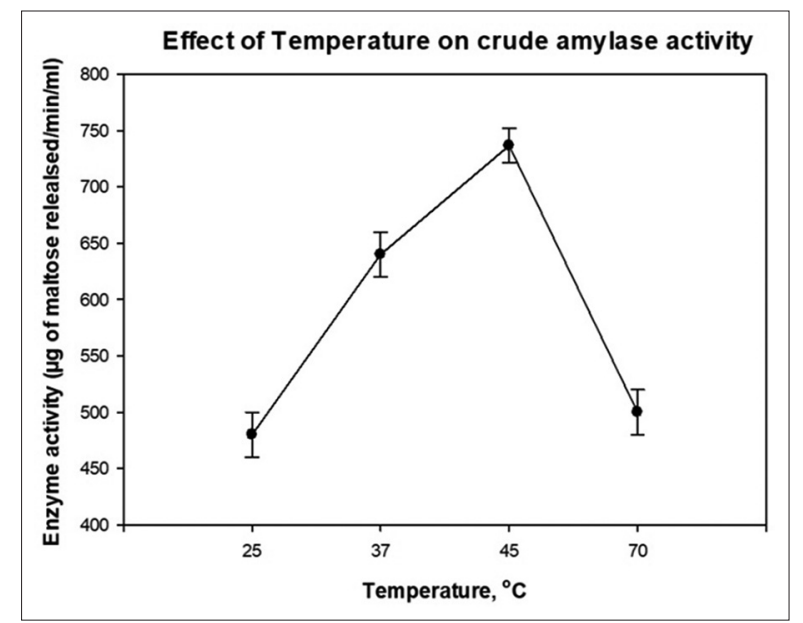

Figure 7: Role of temperature on crude amylase enzyme activity in strain RU1. Bars signify standard deviations for three replicates.

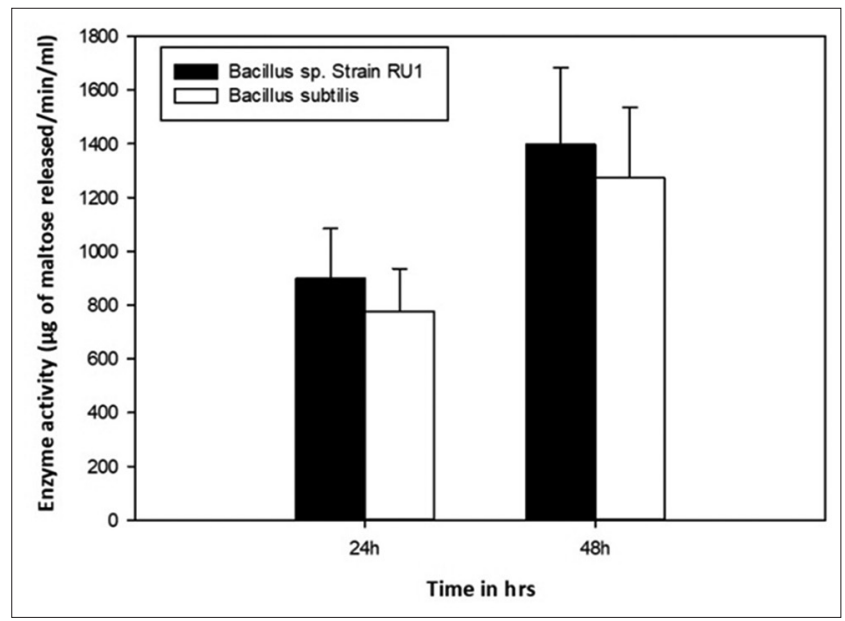

Figure 8: Comparison of amylase enzyme activities of Bacillus sp. strain RU1 with Bacillus subtilis. Bars signify standard deviations for three replicates.

\subsection{Comparison of Amylase Activity of Bacillus sp. Strain RU1 with $B$. subtilis}

To know the potential of Bacillus sp. strain RU1 in terms of amylase activity, an experiment was done by growing the $B$. subtilis under same experimental conditions as that of Bacillus sp. strain RU1. We found that the amylase activity of Bacillus sp. strain RU1 was relatively more when compared with B. subtilis [Figure 8].

\section{CONCLUSION}

Bacillus sp. strain RU1 isolated in the present study has produced an amylase which is moderately thermophilic and alkaline in nature. The specific characteristics of this amylase can be exploited in various industrial processes. It can withstand the heat generated during industrial processes and also can be stable at alkaline $\mathrm{pH}$. Furthermore, the amylase activity of Bacillus sp. strain RU1 was high when compared with amylase activity of $B$. subtilis. Hence, the amylase isolated in the present study can become a good candidate for industrial applications.

\section{ACKNOWLEDGMENTS}

Pinjari Aleem Basha, gratefully acknowledges DST-SERB, Government of India, for financial support in the form of DST-Young Scientist under the SERB File No: YSS/2015/000860.

\section{REFERENCES}

1. Pandey A, Nigam P, Soccol CR, Soccol VT, Singh D, Mohan R, et al. Advances in microbial amylases. Biotechnol Appl Biochem 2000;31:135-52.

2. Schmidt S, Martin A, Schadt C, Lipson D, Meyer A, Costello E, et al. Profound Seasonal Changes in Microbial Diversity and Function in an Alpine Environment. New York: Mc-Graw Hill; 2005.

3. Sindhu MK, Singh BK, Prased T. Changes in starch content of anhar seed due to fungal attack. Phytopathology 1997;34:269-71.

4. Rao MB, Tanksale AM, Ghatge MS, Deshpande VV. Molecular and biotechnological aspects of microbial proteases. Microbiol Mol Biol Rev 1998;62:597-635.

5. Ashwini K, Gaurav K, Karthik L, Bhaskara Rao KV. Optimization, production and partial purification of extracellular $\alpha$-amylase from Bacillus sp. Marini. Arch Appl Sci Res 2011;3:33-42.

6. Lévêque E, Janeček Š, Haye B, Belarbi A. Thermophilic archaeal amylolytic enzymes. Enzyme Microb Technol 2000;26:3-14.

7. Vijayalakshmi, Sushma K, Abha S, Chander P. Isolation and characterization of Bacillus subtilis $\mathrm{KC} 3$ for amylolytic activity. Int J Biosci Biochem Bioinf 2012;2:336.

8. Gupta R, Gigras P, Mohapatra H, Goswami VK, Chauhan B. Microbial $\alpha$-amylases: A biotechnological perspective. Process Biochem 2003;38:1599-616.

9. Nielsen JE, Borchert TV. Protein engineering of bacterial alphaamylases. Biochim Biophys Acta 2000;1543:253-74.

10. Sivaramakrishan S, Gangadharan D, Nampoothiri KM, Soccol CR, Pandey A. $\alpha$-amylases from microbial sources-an overview on recent developments. Food Technol Biotechnol 2006;44:173-84.

11. Mishra S, Behera N. Amylase activity of a starch degrading bacteria isolated from soil receiving kitchen wastes. Afr J Biotechnol 2008;7:3326-31.

12. Holt JG. Gram-positive cocci. Bergey's Manual of Determinative Bacteriology. Maryland: Williams and Wilkins; 1994:527-58.

13. Bernfeld P. Amylase, $\alpha$ and $\beta$. Methods Enzymol 1955;1:149-51.

14. Van Der Maarel MJ, Van Der Veen B, Uitdehaag JC, Leemhuis H, Dijkhuizen L. Properties and applications of starchconverting enzymes of the $\alpha$-amylase family. J Biotechnol 2002;94:137-55. 
15. Grata K, Nabrdalik M, Latała A. Effect of different environmental factors on amylolytic activity of Bacillus cereus and Bacillus mycoides. Proc ECOpole 2010;4:49-53.

16. Salva TD, Moraes IO. Effect of the carbon source on alpha-amylase production by Bacillus subtilis BA-04. Rev Microbiol 1995;26:46-51.

17. Aqeel BM, Umar DM. Effect of alternative carbon and nitrogen sources on production of alpha-amylase by Bacillus megaterium. J Biotechnol 2008;136:S293.

18. Suman S, Ramesh K. Production of a thermostable extracellular amylase from thermophilic Bacillus species. J Pharm Sci Res 2010;2:149-54.

19. Lin LL, Chyau CC, Hsu WH. Production and properties of a rawstarch-degrading amylase from the thermophilic and alkaliphilic Bacillus sp. TS-23. Biotechnol Appl Biochem 1998;28:61-8.

20. Forgaty W, Kelly C. Amylase, amyloglucosidase and related gluconases. Microbial Enzymes and Bioconversions Economic Microbiology. Vol. 5. London: Academic Press; 1980. p. 115-70.

21. van Hille RP, Bromfield LV, Botha SS, Jones G, van Zyl AW, Harrison ST. The effect of nutrient supplementation on growth and leaching performance of bioleaching bacteria. Adv Mater Res 2009;71:413-6.

22. Rasooli I, Astaneh SD, Borna H, Barchini KA. A thermostable $\alpha$-amylase producing natural variant of Bacillus spp. isolated from soil in Iran. Am J Agric Biol Sci 2008;3:591-6.

23. Dash BK, Rahman MM, Sarker PK. Molecular identification of a newly isolated Bacillus subtilis BI19 and optimization of production conditions for enhanced production of extracellular amylase. Biomed Res Int 2015;2015:859805.

24. Ikram-Ul-Haq NS, Shamim N, Ashraf H, Ali S, Qadeer M. Effect of surfactants on the biosynthesis of alpha amylase by Bacillus subtilis
GCBM-25. Pak J Bot 2005;37:373-9.

25. Raza SK. Effect of Pigment Volume Concentration on the Enzyme Activity of Bioactive Coatings. Karlstad: Master of Science in Engineering, Faculty of Technology and Science, Karlstads University; 2011. p. 66.

26. Swain MR, Kar S, Padmaja G, Ray RC. Partial characterization and optimization of production of extracellular alpha-amylase from Bacillus subtilis isolated from culturable cow dung microflora. Polish J Microbiol 2006;55:289-96.

27. Malhotra R, Noorwez SM, Satyanarayana T. Production and partial characterization of thermostable and calcium-independent $\alpha$-amylase of an extreme thermophile Bacillus thermooleovorans NP54. Lett Appl Microbiol 2000;31:378-84.

28. Alk A, Ibrahim HM. A potential new isolate for the production of a thermostable extracellular-amylase. Afr $\mathrm{J}$ Bacteriol Res 2011;3:129-37.

29. Burhan A, Nisa U, Gökhan C, Ömer C, Ashabil A, Osman G. Enzymatic properties of a novel thermostable, thermophilic, alkaline and chelator resistant amylase from an alkaliphilic Bacillus sp. Isolate ANT-6. Process Biochem 2003;38:1397-403.

30. Vaseekaran S, Balakumar S, Arasaratnam V. Isolation and identification of a bacterial strain producing thermostable a-amylase. Trop Agric Res 2010;22:1-11.

\section{How to cite this article:}

Pinjari AB, Kotari V. Characterization of extracellular amylase from

Bacillus sp. strain RU1. J App Biol Biotech. 2018;6(3):29-34.

DOI: $10.7324 / \mathrm{JABB} .2018 .60305$ 